\title{
ESSENTIAL DRUG MANAGEMENT AT RSU KARSA HUSADA BATU: POLICY IMPLEMENTATION
}

\author{
Setya Haksama ${ }^{1}$, Yeni Farida Istanti² ${ }^{2}$ Windhu Purnomo ${ }^{3}$,Stefanus Supriyanto ${ }^{4}$, Samsul Arifin ${ }^{5}$, \\ Tries Anggraini', Tjatur Prijambodo ${ }^{7}$, Anis Wulandari ${ }^{8}$
}

\author{
${ }^{1,4,8}$ Health Policy and Administration Department, Faculty of Public Health, Universitas Airlangga, Mulyorejo, Surabaya, \\ 60115 \\ ${ }^{2,6}$ Karsa Husada Batu Public Hospital, Jl. Jenderal Ahmad Yani No. 11 - 13, Ngaglik, Batu, 65311, Indonesia \\ ${ }^{3}$ Biostatistic and Demography Department, Faculty of Public Health, Universitas Airlangga, Mulyorejo, Surabaya, 60115 \\ ${ }^{5}$ Rumah Sakit Islam Surabaya, Jl. Ahmad Yani No. 2 - 4, Wonokromo, Surabaya, 60243 \\ ${ }^{7}$ Rumah Sakit Aisyiyah Siti Fatimah, Jl. Raya Kenongo 14 Tulangan, Sidoarjo, 61273, Indonesia
}

Email : setyahaksama@fkm.unair.ac.id

\begin{abstract}
Coordination in a hospital is a necessary process needed to reach the organization's goals. One of the processes that need coordination among cross-functional units is the essential drug procurement. The essential drug in Karsa Husada Batu Public Hospital (RSU Karsa Husada Batu) was often out of stock condition in some specific kinds of drugs. The average of the essential drug out of stock between the year of 2017 until the first semester of 2018 reached $33,73 \%$. This number was far from the ideal standard of $0 \%$ out of stock condition. This research was aimed to recommend better coordination of essential drug management. The study used quantitative research and the data is collected using a questionnaire. The population in this research was all hospital staff who participate in essential drug procurement in RSU Karsa Husada Batu. There were 29 samples as the respondents in this research, which used purposive sampling, and the data collection took place in January until February 2019. The data is analyzed based on distribution analysis. Some communication aspects that has reached good results are intensity $(69,00 \%)$, timing $(65,50 \%)$, accuracy $(79,30 \%)$, and problem-solving $(69,00 \%)$. However, mutual respect $(58,60 \%)$, knowledge sharing $(58,62 \%)$, and goal coordination $(65,52 \%)$ had not reached the targeted result. Mutual respect and goal coordination should be the focus of hospital management to reach the goal of essential drug availability.
\end{abstract}

Keywords: coordination, essential drug, management

\section{INTRODUCTION}

Medicine is a very important component in health care. To ensure the availability, equity and affordability of essential medicines, the Government has issued a national drug policy, including the Minister of Health Regulation No. Hk.02.02 / Menkes / 068 / I / 2010 concerning the Obligation to Use Generic Drugs in Government Health Services, Kepmenkes No. 189 / Menkes / SK / III / 2006 concerning National Drug Policy, and Kepmenkes No. HK.01.07 / Menkes / $659 / 2017$ concerning the National Formulary. This policy is aimed at ensuring the safety, efficacy and quality of drugs in circulation, as well as protecting people from misuse and abuse of drugs. The central and regional governments are responsible for providing essential drugs, so that the availability and affordability of essential drugs and rationalization of drug prices need to be pursued.

In the National Health Insurance (JKN) era, hospital services have become one of the main concerns in health issues. One of the critical needs in hospitals is drug availability. Essential drugs are selected drugs and the most needed drug in health services. Thus, access to drugs, especially essential drug, is one of the human rights. Therefore, regulation of essential drug availability is not only made at the national scale but also in hospitals where the public consumes essential drugs. Based on the National Medicine Policy (KONAS) SKN 2004, KMK No. 004/2003 about decentralization policies and strategies in the health sector and Decree of Health Minister (KMK No. 1457/2003) concerning Minimum Standard of Service, it can be seen that the availability of essential national drug must reach $100 \%$ availability, or must not be out of $\operatorname{stock}[1,2,3]$.

Based on monthly data reports on pharmaceutical installation quality on the quality committee of RSU Karsa Husada Batu in the first and 2nd semester in 2017 and the 1st semester of 2018, the essential drug at RSU Karsa Husada Batu never reached 100\% availability. This condition showed that there are problems in the availability of the essential drug. The essential drug 
supply process, including the management of essential drugs, involved some cross-functional units, which are user, pharmaceutical installations, procurement, recipients of work, warehouse, distribution, and financial unit. Essential drug management involved different units, which makes coordination became very important. Based on the result of previous research about the leadership style of the public government hospital, showed the dominant leadership style from the local province hospital director in Jakarta is supporting leadership style with a high level of flexibility and middle level of effectiveness [4]. Supportive leadership needs excellent two-way communication between the leader with the staff. The involvement of the staff has a big part in achieving the goal. Communication and relation among the staff of each unit or cross-functional unit have a significant role, especially in the coordination of essential drug procurement.

Coordination involves two crucial dimensions, which are the existence of communication and relationships based on relation coordination theory. Relation coordination can affect an organization's ability to achieve its goals. Gittel's description of coordination is that it can occur due to frequent and excellent quality communication and also supported by goals coordination, knowledge sharing, and mutual respect that enable organizations to achieve the goals better. There are higher levels of interdependence between units in managing essential drugs which showed by the characteristics task dependence between individuals or units.

Coordination in the management of essential drugs is needed to prevent delays in processing from one unit to another, such as preventing the delay in submitting the Drug Request Form and Drug Request Report which results in poor planning of amount and time. Besides, the delay can cause ordering and sending drugs until the payments process out of schedule.

Various problems that occur in managing essential drugs in RSU Karsa Husada Batu need to be in the coordination process. This study aims to finds out and analyses the coordination in managing essential drugs at RSU Karsa Husada Batu. The result expected can be valuable information for policymakers' reference in order to improve coordination among the essential drug management at the public hospital.

\section{METHOD}

This research is a quantitative study with a crosssectional approach and studied the picture of coordination between each unit in RSU Karsa Husada Batu involved in essential drug management. The population in this study were hospital staff involved in essential drug management. There were 29 respondents consist of four people from the user, four people from pharmacy installations, five people from the procurement team, four people from the recipient unit, four people from the warehouse unit, and four people from the distribution department. The sample was determined by purposive sampling to ensure that the information obtained was from those directly involved in essential drug management.

This research studied variables of communication, which are intensity, timing, accuracy, problem-solving, knowledge sharing, mutual respect, and goal coordination. The study used a questionnaire as the instrument of the study, which has been tested for validity and reliability. The data obtained were analyzed using a distribution analysis.

\section{RESULT AND DISCUSSION}

This study involved essential drug management staff at RSU Karsa Husada Batu. The process needs a particular time for respondents to be able to fill out questionnaires and not interfering with their working hours. Based on the results of the study, the description of the respondents written as follows.

\begin{tabular}{cccc}
\multicolumn{5}{c}{ Tabel. 1 Respondents Characteristics } \\
\hline No & Characteristic & $\mathrm{n}$ & $\%$ \\
\hline Gender & Male & 12 & 41,38 \\
1 & Female & 17 & 58,62 \\
2 & & & \\
Age & $18-21$ years old & 0 & 0,00 \\
1 & $22-25$ years old & 3 & 10,34 \\
2 & $26-35$ years old & 13 & 44,83 \\
3 & $\leq 55$ years old & 13 & 44,83 \\
4 & Diploma & 5 & 17,24 \\
Education Background & High School or Health Vocational High School & 7 & 24,14 \\
1 & Undergraduate & 17 & 58,62 \\
2 & $\leq 3$ years & & \\
3 & $>3$ years & 13 & 44,80 \\
Length of work experiences (at RSU Karsa Husada Batu) & 16 & 55,20 \\
1 & & & \\
2 & & & \\
\hline \multicolumn{4}{c}{}
\end{tabular}

The results from the questionnaire have been analyzed by distribution analysis resulted in an overview of each variable. The following variables come from two dimensions of coordination, which are communication and relationships. The dimension of communication consists of intensity, timing, accuracy, and problemsolving. Communication is an essential factor for selecting, developing, and appreciating organizational members as well as leading, directing, motivating, and creating a work climate that includes member participation.

Intense communication has a vital role in work coordination - the results of the intensity of communication identified as follows. 


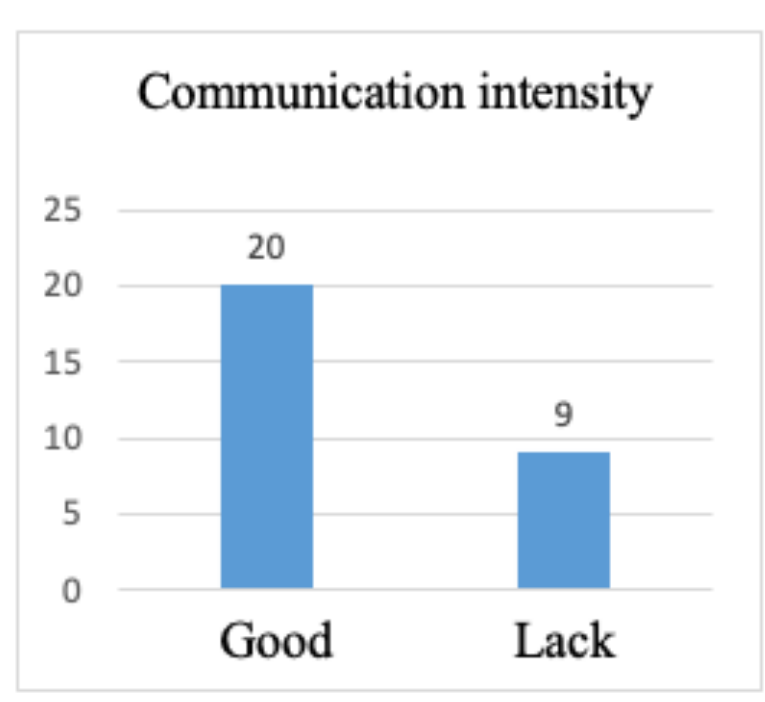

Graph 1. Communication intensity

Twenty respondents $(69 \%)$ stated that the intensity of communication had gone well. This result shows that communication often happens among the staff. The results of the communication timing showed in the following graph.

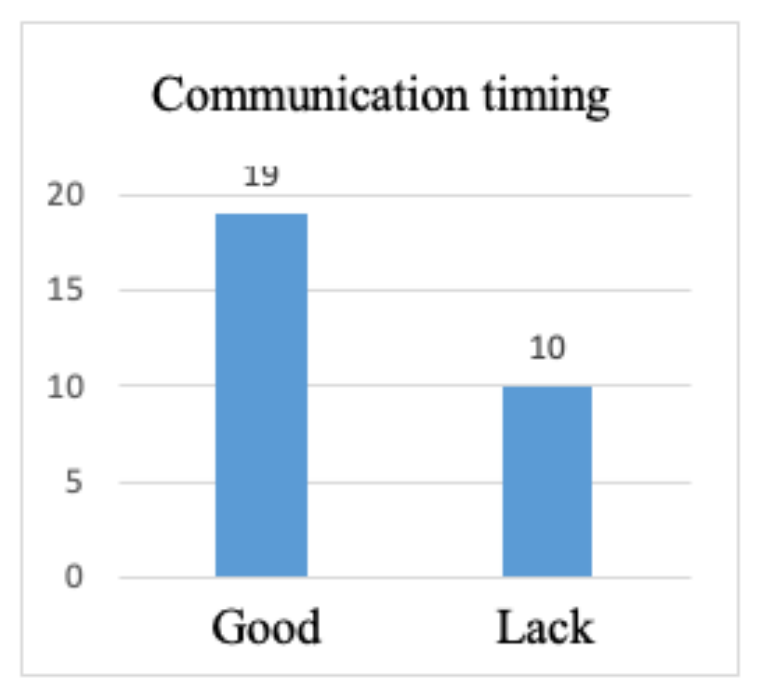

Graph 2. Timely Communication

Communication timing, according to 19 respondents $(65,5 \%)$, was good. Also, there is a variable communication accuracy, which means how accurate and reliable the information provided by one unit and another - the results of respondents' assessment of the communication accuracy showed as follows.

\section{Communication accuracy}

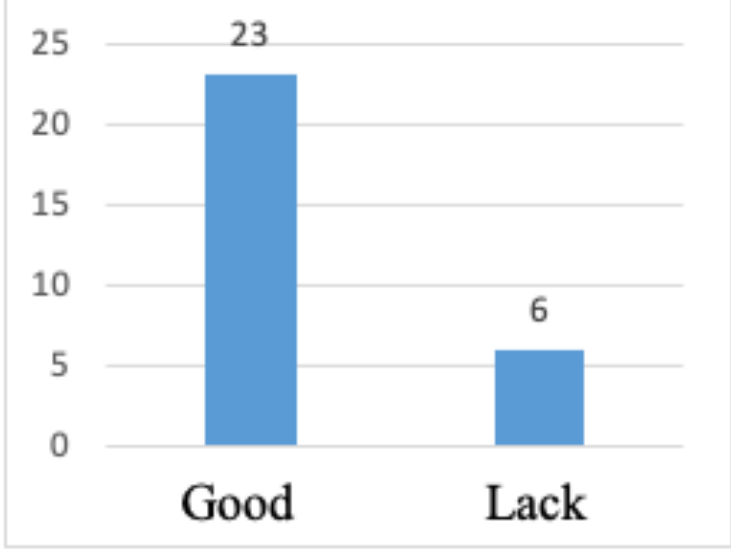

Graph 3. Communication Accuracy

The 23 respondents $(79,3 \%)$ stated that the information provided was accurate. The results of the measurement of communication variables in problem-solving communication showed as follows.

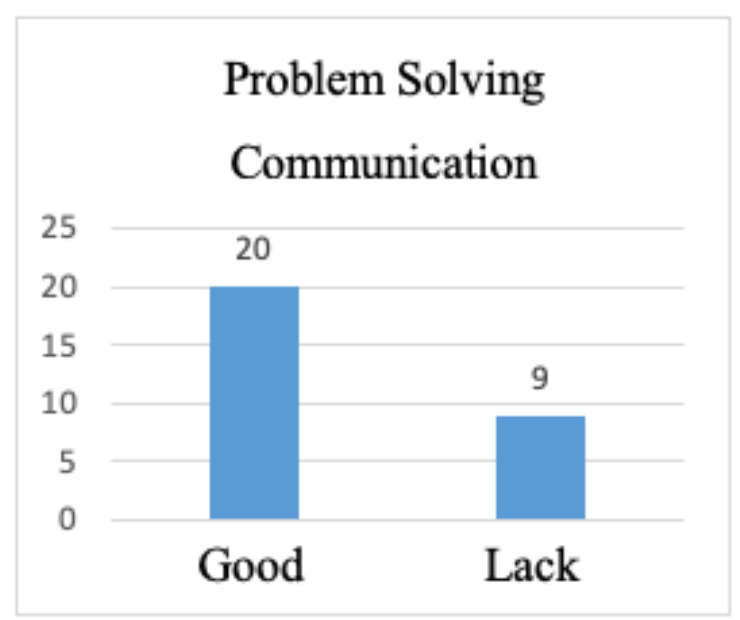

\section{Graph 4. Problem Solving Communication}

There were 20 people (69\%) who stated that problemsolving communication in essential drug management has been good. The second dimension of coordination is the relationship between units which assessed from shared goals, shared knowledge, and mutual respect. The 19 respondents $(65,5 \%)$ stated that each unit in managing the essential drug was still lack of goals coordination. We can see the result of the measurement of goals coordination in graphic 5 . 


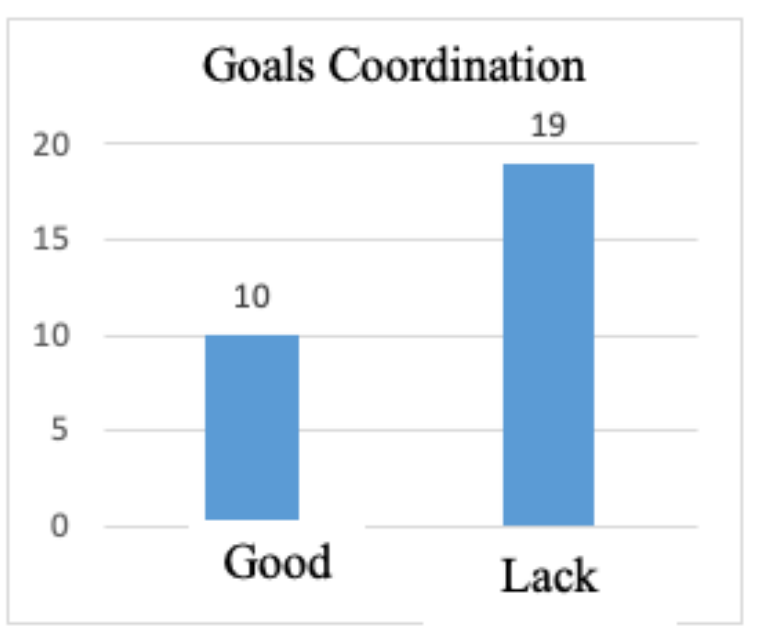

Graph 5. Shared Goals

According to 17 respondents $(58,62 \%)$, units who manage the essential drugs were still lack of knowledge sharing. Graphic 6 shows the result of knowledge sharing.

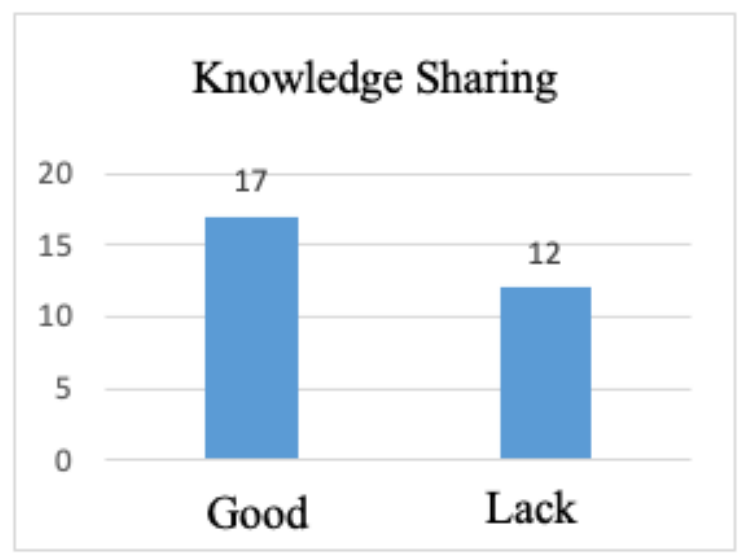

Graph 6. Shared Knowledge

Graphic 7 shows the result of mutual respect in communication. The 17 respondents $(58,6 \%)$ stated that management units for the essential drug were still lack of mutual respect. This indicates that willingness and ability to respect each other's role in essential drug management is still low.

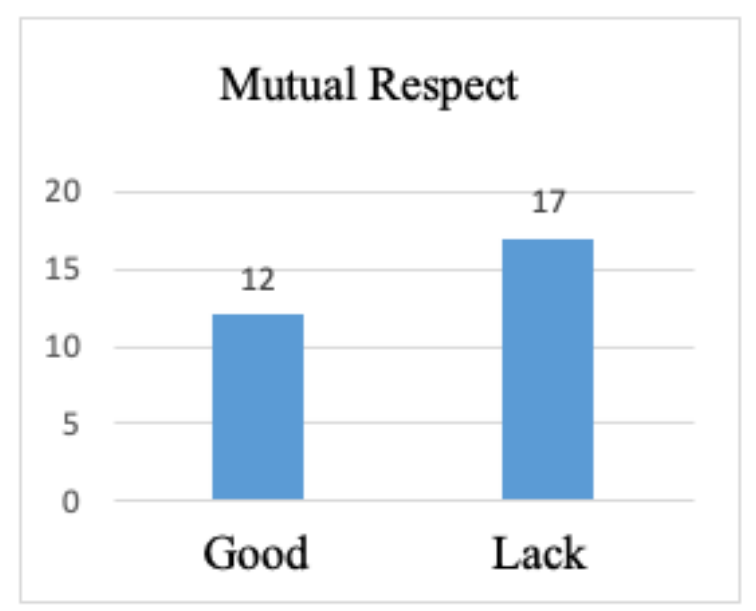

\section{Graph 7. Mutual Respect}

Essential drugs are one of the logistics that must be available at the hospital. Health services availability is related to not only the use of material resources but also the aspect of coordination. Coordination among units in the essential drug management has a high level of needs and mutual needs between each unit involved in ensuring that the essential drugs are available.

Coordination is a synchronous effort to provide the number of goods which not only in the right amount but also at the right time. The implementation process of achieving the organization's goals need to be directed to produce a uniform and harmonious action. So that, coordination can not be separated from communication. Communication is the process of transmitting information and common understanding from one person to another [5]. Every administrative function and activity involves some form of direct and indirect communication. Whether planning, organizing, or leading, and monitoring [6]. The need for coordination depends on the tasks and the degree of interdependence of various units in implementation [7]. The relation between coordination and communication are inseparable things. Drug management requires communication from various units involved because, through excellent communication, each unit involved can receive various information related to drug management.

Low-quality communication that includes aspects of infrequent, delayed, inaccurate, and finger-pointing communication can affect the quality of the relationship, forming unfunctional goals, unshared knowledge, and disrespect towards others [8]. Ineffective communication in an organization may result in uncertainty, apprehension, and dissatisfaction, which results in reduced productivity [10]. Communication is the delivery of information from communicators to communicants that can be understood. Coordination requires productive communication which happens quickly or fast, in a sufficient amount, and on time. Communication consists of sources, massages, media, communicants, 
and feedback. The function of communications is to integrate organized activities. This function also has been stated in the previous research that reveals the relationship exists on the balance of effective communication, workers' performance, productivity, and commitment [6]. The needs of coordination are fundamental to be applied, especially for hospitals in maintaining the quality of health services provided [7]. Based on the result, communication accuracy has reached the highest percentage $(79.30 \%)$ among other variables of communication in coordination. Communication accuracy means that the message is successfully sent to the receiver; this definition has a similarity with effective communication. The previous study has stated that there is a relationship between the communication approach and efficient organizational performance [10].

Communication between each unit in essential drug management at RSU Karsa Husada Batu has been going well seen from the intensity, timing, accuracy, and problem-solving aspect of communication. Therefore, problem-solving communication is still incidental and only happens when it is necessary. However, the dimensions of the relationship still tend to be weak. The goals of coordination and mutual respect were still low. The goals coordination agenda among units in essential drug management at RSU Karsa Husada Batu has not been scheduled regularly in the cross-functional team meetings. This problem caused the lack of unity in achieving the organization's outcome, specifically in ensuring the availability of the essential drug. Each unit has various service-focused goals as its target [11]. The quality of the hospital needs to be maintained by performance appraisal to make sure of hospital goals attainment [12].

Based on the result, there are four out of six variables that have been achieved at a good level. This result can be affected by the educational background of RSU Karsa Husada staff that mostly consists of undergraduates $(58,6 \%)$. This result is supported by the previous research that showed the higher the education level, the more effects on education and skill on job performance. As the level of their education determines such people able to understand and use advanced technology. Educated workers tend to be more responsive in receiving instructions and doing new tasks and quickly adopt new technology, which increases their ability to innovate and improve job performance [13]. Besides, low mutual respect among units can be a treat for the coordination outcomes because to provide essential drug needs the unity of goals among units. All units, consist of the user, planning, procurement, job-receiving team, warehouse, distribution, and finance, have critical roles. Even though knowledge sharing still has a good result, but when the goals are still not aligned, each unit might prioritize different things.

\section{CONCLUSION}

Some communication aspects reached good results are intensity $(69,00 \%)$, timing $(65,50 \%)$, accuracy $(79,30 \%)$, and problem-solving $(69,00 \%)$. However, mutual respect $(58,60 \%)$, knowledge sharing $(58,62 \%)$, and goal coordination $(65,52 \%)$ had not reached the targeted result. Mutual respect and goal coordination should be the focus of hospital management to reach the goal of essential drug availability.

\section{RECOMMENDATION}

Further research which involved the discussion among unit or even cross-functional unit is needed to build more respect towards each other and understand the common goal of essential drug availability. Policymakers, directors, and departments need to oversee the essential drug management units to build the shared goals in order to reduce the stock out of the essential drug at RSU Karsa Husada Batu. Besides, we need to build mutual respect between units in essential drug management by understanding the role of each unit to reach the same goal, which is the availability of essential drugs.

\section{ACKNOWLEDGMENT}

Appreciation and gratitude express to the Karsa Husada Batu Public Hospital, which has been cooperative in this research.

\section{REFERENCE}

1. Kebijakan Obat Nasional (KONAS) SKN 2004

2. Keputusan Menteri Kesehatan No. 004/2003 Tentang Kebijakan dan Strategi Desentralisasi bidang Kesehatan

3. Keputusan Menteri Kesehatan No. 1457/2003 tentang Standar Pelayanan Minimal (SPM)

4. Rahmah, Balqis. 2010. Kajian Gaya Kepemimpinan Direktur Rumah Sakit Umum Daerah (RSUD) Terhadap Fungsi Kepemimpinan Direktur dalam Pelaksanaan Manajemen RSUD di DKI Jakarta Tahun 2010. Tesis. Program Studi Kajian Administrasi Rumah Sakit, Universitas Indonesia.

5. Lunenburg, Fred, C. 2010. Communication : The Process, Barriers, and Improving Effectiveness. Schooling. Vol 1 (1).

6. Femi, A. Festus. 2014. The Impact of Communication on Workers' Performance in Selected Organisations in Lagos State, Nigeria. IOSR Journal of Humanities and Social Science. Vol 19 (8) Version II.

7. Larasati, S.P \& Haksama ,Setya. 2016. Penerapan Theory of Constraint Pada Kepuasan Kerja Karyawan Rumah Sakit Mata Undaan Surabaya. Jurnal Administrasi Kesehatan Indonesia. Vol 4(2).

8. Gittel, J. H., 2010. A Relational Model of How 
High-Performance Work Systems Work. Organization Science. Vol 21 (2).

9. Lovlyn, E.K-Iloafu. 2016. The Role of Effective Communication in Strategic Management of Organization. International Journal of Humanities and Social Science. Vol 6 (12).

10. Shonubi, A, O \& Akintaro, A, A. 2016. The Impact of Effective Communication on Organizational Performance. Valley International Journals. Vol 3 (3).

11. Choon, T, T \& Patrick, L, K, C. 2016. The Impact of Goal Setting on Employee Effectiveness to Improve Organisation Effectiveness : Empirical Study of a High - Tech Company in Singapore. Journal of Business \& Economic Policy. Vol 3 (1).

12. Haksama, Setya, Lusno, M,F,D, Prayoga, D, Farid, M,R,H, Shedyta, S, S, Shedysni, S,N, \& Mudjanarko, S,W. 2018. Analisis Kinerja Unit Rawat Inap Rumah Sakit X Berdasarkan Kriteria Malcolm Baldrige. Jurnal Sain Health. Vol 2(2).

13. Kasika, Bwendo D. 2015. The Effect of Educational Qualification on Job Performance The Case of Social Security Commission in Namibia (SSC). Accessed in http://hdl.handle.net/11070/1441 